(C) 1991 ISIJ

解 説

解 説

\section{微生物における磁性鉄微粒子}

\title{
松永是* \\ Production of Magnetite Particles in Microorganisms
}

Tadashi Matsunaga

\section{1.はじめに}

LowENSTAM は 1960 年代の始めにヒザラガイの歯に磁 石を近づけたところ鉄粉のように亚ぶものを発見し，こ れがマグネタイト $\left(\mathrm{Fe}_{3} \mathrm{O}_{4}\right)$ であることを確認した ${ }^{1)}$. これが生物から発見された最初の磁性体であった。 その 後, 1970 年代のなかば BLAKEMORE により菌体内に磁気 微粒子を持つ微生物, 走磁性細菌が発見された ${ }^{2)}$.さら にミッバチ，ハト，マグロ，サケなどの動物でも磁気微 粒子の存在が確認された。生物が合成する磁気微粒子は 単磁区構造をとるため磁気モーメントが大きく，粒子径 も 50 〜 $150 \mathrm{~nm}$ 程度であり，形状も揃っているなどの特 性を有している。しかしながら，その役割や働きはまだ 十分に解明されていない。本稿では，微生物における鉄 微粒子 (磁性体) を中心に, その生成メカニズム, キャ ラクタリゼーション，忍用などについて述べる．

\section{2. 生物由来の磁石}

\section{$2 \cdot 1$ 動物}

ハト, 渡り鳥,ミッバチなどは地磁気を感知し，その 連動・行動方向を定めていると推走された。ハトの首や 頭部に残留磁気を示す部分がみられ，その部分を電子プ ローブX 線マイクロアナライザーにより解析したとこ ろマグネタイトが局在することが明らかになった。この 残留磁化を示す部分は神経組織を含んでおり，組織内に はフェリチンと推定される鉄含有タンパク質が含まれて いた：この他，マグロやサケなどの回遊魚において，マ グネタイトが鼻腔域にある中篩骨 (Mesethmoid bone) に存在していることが確認されだ). 抽出されたマグネ タイトはキャラクタリゼーションも行われているが，い ずれも単磁区構造をとっていることが明らかになっ だ). ベニザケ Oncorhynchus nerka から抽出された単 磁区のマグネタイトの粒子径は 25 60 nm（平均 $48 \mathrm{~nm}$ )
で，粒子は鎖状の形態で存在しており ${ }^{5)}$, さらに生育と ともに，マグネタイト粒子由来の磁化が増大しているこ とも報告されている6 ${ }^{6}$.この他にもエビ，カメなどから も残留磁気を示す部分が頭部でみられ，その解析が行わ れている.

この他，ミッバチにも腹部の組織中にマグネタイトの 存在が確認されている．また：ミッバチを $100 \mathrm{mT}$ のパ ルス磁場中にさらすことにより，この磁場がミッバチの 行動に影響を与え，方问感覚を狂わせることを示してい る.しかも，ミッバチはパルス磁場に対する学羽効果も 示した7).

磁気を感じる生物には，この磁気微粒子と神経系組織 の複合体からなる磁気センサーらしきものの存在が推測 されている．磁気微粒子が関与した磁気感覚モデルにつ いては，いくつか報告があるが，まだその機構を解明す るに至っていない. 動物は微生物とは其なり, 高度に分 化された多くの感覚細胞を持っているが，その中の一つ に運動方向や重力方向を感じる有毛䋞胞がある。おそら く, 磁気感覚器も, この組織に類似したものと仮定され る.

\section{$2 \cdot 2$ 微生物}

微生物の中で, 走磁性細菌 (Aquaspirillum magnetotacticum) は，その菌体内に $50 \sim 100 \mathrm{~nm}$ のマグネタイ トの微粒子が 10 20 個ほど連なったマグネトソームを 保持している。これで地磁気を感知し, 磁力線の方们を 認識することができる。この細菌は北半球では北 ( $\mathrm{S}$ 極) に, 南半球においては南（ $\mathrm{N}$ 極）に们かって泳ぐこと が知られている. 海洋の堆積物表層にも走磁性細菌が確 認された。磁気を示す微粒子の構造は単磁区であった。 堆積物中の走磁性細菌の分布と磁気の強さに相関関係が 認められ，SToL. らは堆積物中の残留磁化の源が走磁性 細菌だと推定している ${ }^{8)}$ 。この他, 磁気に答する藻 (Anisoneme sp.) が発見され，マグネトソーム状の磁

平成 2 年 12 月 10 日受付 (Received Dec. 10, 1990) (依頼解説)

* 束宗農I大学I学部教授 I博 (Faculty of Engineering, Tokyo University of Agriculture and Technology, 2-24-16 Naka-cho Koganei, Tokyo 184)

Key words : magnetic bacteria ; magnetosome ; fluoroimmunoassay; phagocytosis ; micro magnetic sensor. 
気微粒子の鎖が細胞壁の近くに存在していることが確認 された ${ }^{9)}$ 。このような微生物はマグネトソームを保持す ることで磁力線方们に配们することができる。すなわち， 地磁気がマグネトソームを有する走磁性を示す微生物の 連動方向を決定していることが示された。したがって， 微生物の菌体内でマグネトソームは, 磁気を感知するコ ンパスとなっていると推定されている.

また最近，嫌気条件下でもマグネタイトをつくる細菌 （GS-15）が発見された。この GS-15 は走磁性を示さ ないが，代謝の最終電子受谷体として 3 価の鉄を還元す るときに菌体外にマグネタイトを作り出す，GS-15は 嫌気条件下で, その增殖の際，有機物の酸化と 3 価の鉄 の還元を行う. $1 \mathrm{~mol}$ の酢酸塩を分解する際に, $8 \mathrm{~mol}$ の $\mathrm{Fe}^{3+}$ を $\mathrm{Fe}^{2+}$ に還元する。走磁性細菌が菌体内の 磁気微粒子を方向性決定に利用しているのに対し, GS-15 が命成する磁気微粒子は，代謝の途中での副産 物で, その他の生物学的意味はないと考えられる.

電子供与体としての酢酸塩と $0.2 \mathrm{~mol} / \mathrm{l}$ の 3 価鉄イオ ンを含む培地で，気相を窒素置換し GS-15 を培養した ところ, GS-15 の增殖につれて, 磁性を带びていない 茶色のアモルファス酸化鉄は黑色の磁気微粒子に変化 した．黑色の磁気微粒子は GS-15 を植菌しなかった場 合には生成がみられないことより，磁気微粒子の合成に は GS-15 の代謝が関与していると考えられる。また， GS-15は菌体 $10 \mathrm{~g}$ 当たり $1 \mathrm{~kg}$ の磁気微粒子を合成す る能力を持っていた。この磁気微粒子を透過型電子顕微 鏡で観察したところ, 粒往 10～50 nm の結唱の凝集塊 が見られた．X 線エネルギー分散型分析装置による分 析により鉄が検出され，さらに電子線回折によりここの 磁気微粒子はマグネタイトであることが示された。また， ローリー・フーリエ・テストにより，この磁気微粒子は単 磁区構造を示した。これらの結果より，GS-15 は嫌気 的な条件下で有機物を酸化し， 3 価の鉄を還元する際， 多量のマグネタイトを合成することができると考えられ $3^{10)}$.

\section{3. 微生物由来の磁気微粒子の分離と キャラクタリゼーション}

\section{$3 \cdot 1$ 走磁性細菌の培養}

淡水性らせん菌の Aquaspirillum magnetotacticum MS-1 株の単離が行われ ${ }^{11)}$, MOENCH らは球菌の走磁性 細菌を磁力により濃縮, 純粋化し, グラム除性菌である こと, 鉄含有量は乾燥菌体重量当たり $3.8 \%$ であるこ とを示した ${ }^{12)}$. BAZYIINSKI らは, 嫌気条件下で菌体内に マグネタイトを令成する海洋性走磁性細菌 MV-1 株の 単離を行った $\left.{ }^{13}\right)$. MV-1 は亚酸化窒素 $\left(\mathrm{N}_{2} \mathrm{O}\right)$ で置換し た培地でキナ酸鉄を鉄源として培養すると，10 個ほど のマグネタイト微粒子が連なったマグネトンームを命成 する.その粒径は $40 ６ 0 \mathrm{~nm}$ で, 乾燥菌体重量の約 1.6

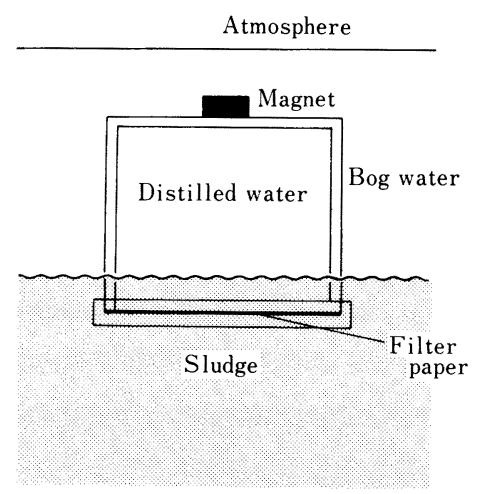

Fig. 1. Harvesting apparatus of magnetotactic bacteria.

\%を占めていた. MV-1 は $\mathrm{N}_{2} \mathrm{O}$ を最終電子受容体とし て嫌気呼吸を行い， $\mathrm{N}_{2} \mathrm{O}$ を $\mathrm{N}_{2}$ に還元する。 このこと からマグネタイト合成には酸素を必要とせず，また，海 洋の堆積物中に $\mathrm{N}_{2} \mathrm{O}$ が存在することから, 嫌気的な堆 積物中の残留磁化の根源の一つとして考えられてい $3^{13)}$.

筆者らは，走磁性細菌を国内の池や沼，湖，海岸など から分離した．Fig. 1 に示したような円柱状の容器に イオン交換した蒸留水を満たして, 容器の上にサマリウ ムーコバルト $(\mathrm{Sm}-\mathrm{Co})$ 磁石の $\mathrm{S}$ 極を置き，下にろ紙を 取り付けて池, 沼, 海岸などの泥や砂の上に数時間放置 すると, 数種類の走磁性細菌が菌数にして $10^{7} \sim 10^{9}$ 個 集まった。また，泥や砂の表層数 $\mathrm{cm}$ のところを取って きて, 容器に入れ側面に磁石の $\mathrm{S}$ 極を置き光学顕微鏡 で観祭したところ，6〜7種の走磁性細菌が確認できた。 走磁性細菌は菌体内に十数個の磁気微粒子が連なった チェーン (マグネトソーム) を有し, べん毛により連動 することが確認された。ささらに, 走磁性細菌のスクリー ニング, 単菌分離を行ったところ, 好気的な条件下で 增殖叮能ならせん状の走磁性細菌の分離に成功した (Photo. 1)。この走磁性細菌を炭素源にコハク酸, 究素 源に硝酸ナトリウム, 鉄源にキナ酸鉄を含むMSGM 培 地で培養したところ, 培養後 4〜5 日で定常に達し, 細 胞は $5 \times 10^{8} \mathrm{cell} / \mathrm{ml}$ まで増殖叮能であった。

培地中の鉄イオン濃度を $1.7 \mathrm{mg} / \mathrm{l}$ とした場命, 培養 4 日後で 71 の培地より $138 \mathrm{mg}$ の乾燥菌体が得られ, 菌体の $2.5 \%$ にあたる $3.5 \mathrm{mg}$ の磁性細菌粒子が抽出さ れた。このとき, 培地中の鉄イオンの減少が確認され, 磁性細菌粒子の合成に用いられた培地中の鉄イオンの量 は $2.5 \mathrm{mg}$ であった。この結果, 培地中の鉄イオンのほ とんどが取り込まれて, 磁性細菌粒子の生成に用いられ ているということが明らかになった。しかしながら，培 地中に鉄イオンが全く含まれていない場命, 走磁性細菌 の增殖は見られなかった。このことから，走磁性細菌の 
Table 1. Separation of bacterial magnetic particles from magnetotactic bacteria by various treatments.

\begin{tabular}{|c|c|c|c|c|c|c|}
\hline \multirow[b]{2}{*}{ Treatment } & \multirow{2}{*}{$\begin{array}{l}\text { Membrane } \\
\text { thickness } \\
(\AA)\end{array}$} & \multirow{2}{*}{$\begin{array}{l}\text { Median }^{\text {a) }} \\
\text { diameter } \\
(\mu \mathrm{m})\end{array}$} & \multirow{2}{*}{$\begin{array}{l}\text { Surface } \\
\text { area } \\
\left(\mathrm{m}^{2} / \mathrm{g}\right)\end{array}$} & \multicolumn{3}{|c|}{$\left.t_{a}=0.5 a_{0}(\min )^{b}\right)$} \\
\hline & & & & 250 & $\begin{array}{c}125 \\
(\mu \mathrm{g} / \mathrm{ml})\end{array}$ & 63 \\
\hline $\begin{array}{l}\text { Ultrasonication } \\
\text { Lysozyme } \\
\text { Lysozyme }+\mathrm{NaOH} \\
\text { Ultrasonication }+ \text { Chloroform-methanol }\end{array}$ & $\begin{array}{r}44 \\
36 \\
35 \\
0\end{array}$ & $\begin{array}{r}0.12 \\
0.94 \\
1.87 \\
12.52\end{array}$ & $\begin{array}{r}12.84 \\
3.08 \\
0.98 \\
0.30\end{array}$ & $\begin{array}{l}35.0 \\
24.0 \\
10.7\end{array}$ & $\begin{array}{l}63.0 \\
46.0 \\
\overline{14.0}\end{array}$ & $\begin{array}{r}124.0 \\
102.0 \\
43.0 \\
30.0\end{array}$ \\
\hline
\end{tabular}

a) Particle concentration was adjusted to approximately $130 \mu \mathrm{g} / \mathrm{ml}$ (absorbance 100) for particle size analysis.

b) Absorbance $(a)$ of particle suspension was measured at $660 \mathrm{~nm}$.

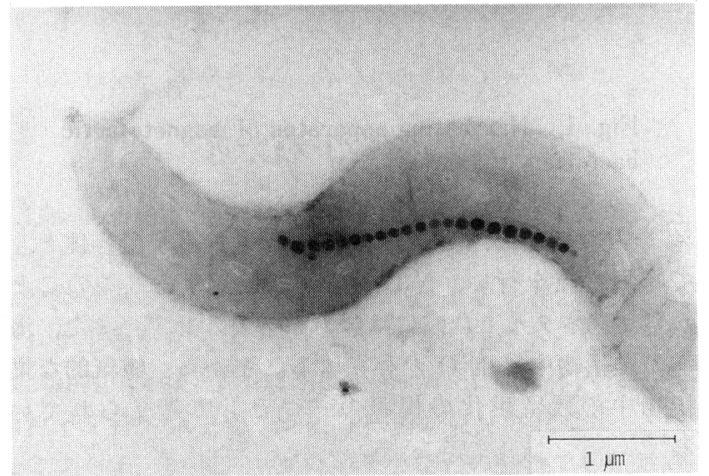

Photo. 1. Transmission electron micrograph of magnetotactic bacteria.

増殖には鉄イオンが必要であることがわかった。

\section{$3 \cdot 2$ 磁性細菌粒子のキャラクタリゼーション}

磁性細菌粒子のキャラクタリゼーションについては, すでに電子線回折 ${ }^{14)}$, 高分解能透過型電子顕微鏡 ${ }^{15)}$, メスバウアー分光法などを用いて行われている.

まずさまざまな方法で分離した磁性細菌粒子の特性に ついて Table 1 にまとめた，超音波処理で分離した場 合，平均粒子径は $0.12 \mu \mathrm{m}$ であった。粒子を $63 \mu \mathrm{g} / \mathrm{ml}$ の濃度に懸濁すると吸光度 $(660 \mathrm{~nm})$ が半減する時間は $124 \min$ と，人士のマグネタイト微粒子に比べ，非常に 分散性に優れていた。リゾチーム処理で分離すると, 磁 性細菌粒子が凝集して, 平均粒子径が $0.94 \mu \mathrm{m}$ となっ た.さらに, アルカリ $(5 \mathrm{~N} \mathrm{NaOH})$ 処理を行うと, より 大きな凝集を形成した。超音波処理により分離した磁性 細菌粒子をクロロホルムーメタノール $(2: 1 \mathrm{v} / \mathrm{v})$ で処理 すると，磁性細菌粒子を覆っていた有機薄膜の存在は認 められなくなり, 平均粒子径も $12.52 \mu \mathrm{m}$ と非常に大き な凝集塊を形成した。このように，分離方法を変えるこ とでさまざまな大きさの磁性細菌粒子を調製することが できた。また，この有機薄膜が磁性細菌粒子の分散性に 関与していることが示された。

磁性細菌粒子をエネルギー分散型 X 線分析装置によ り分析したところ，主成分が鉄および酸素であることか ら, 磁気微粒子は鉄の酸化物 $\left(\mathrm{FeO}, \mathrm{Fe}_{2} \mathrm{O}_{3}, \mathrm{Fe}_{3} \mathrm{O}_{4}\right)$ で あると考えられた。そこで電子線回折分析を行ったとこ
Table 2. Fatty acid composition of magnetosome membrane.

\begin{tabular}{|c|c|}
\hline Fatty acid & $\begin{array}{l}\text { Amounts of fatty acid } \\
(\mu \mathrm{g} / \mathrm{mg} \text { magnetosome })\end{array}$ \\
\hline $\begin{array}{l}\mathrm{C}_{12: 0} \\
\mathrm{C}_{14: 0} \\
\mathrm{C}_{16: 0} \\
\mathrm{C}_{16: 1} \\
\mathrm{C}_{18} \dot{1}^{1} \\
\mathrm{TF} \mathrm{A}^{2}\end{array}$ & $\begin{array}{rr}0.08 & (0.3 \%) \\
0.24 & (0.8 \%) \\
2.94 & (9.2 \%) \\
13.81 & (43.4 \%) \\
14.72 & (46.3 \%) \\
31.79 & (100.0 \%)\end{array}$ \\
\hline
\end{tabular}

TFA : Total Fatty Acid

ろ, 電子線回折パターンは純粋なマグネタイトのパター ンと一致した。また, 高分解能透過型電子顕微鏡で結晶 の各面の格子間距離を測定したところ，人上のマグネタ イトとほぼ一致した。

以上の結果から, 分離した磁性細菌粒子もマグネタイ トの結晶であることが示された。この磁性細菌粒子の大 きさ, 形状を解析したところ, 単磁区の磁気微粒子であ ることが確認された。磁化特性も人工のマグネタイトと ほぼ一致した。

また，クロロホルムーメタノールで処理したときに膜 の存在が認められなかったことから, 脂質が有機薄膜の 構成成分になっていると推察された。 そこで, 有機薄膜 の脂質成分について薄層クロマトグラフィー（TLC）を 用いて分析した。磁性細菌粒子からクロロホルムーメ夕 ノールで膜の脂質分を抽出したところ, 磁性細菌粒子 $13.5 \mathrm{mg}$ から脂質 $1.59 \mathrm{mg}$ が分離された。展開溶媒にク ロロホルムーメ夕ノールー水 $(65: 25: 4)$ を用いて TLC を行ったところ, 脂質成分中に 3 種のりん脂質が検出さ れた。このりん脂質の一つはホスファチジルエタノール アミン（PE）であることが明らかになった。りん脂質 は磁性細菌粒子 $1 \mathrm{mg}$ 当たり $68 \mu \mathrm{g}$ で, 全脂質の $58 \%$ を, PE は磁性細菌粒子 $1 \mathrm{mg}$ 当たり $34 \mu \mathrm{g}$ で, りん脂 質の $50 \%$ を占めていることが明らかになった。さらに， 抽出した脂質の脂肪酸組成を調べた。塩酸一メタノール でメチルエステル化した脂肪酸をガスクロマトグラ フィーで分析したところ， 3 種類の飽和脂肪酸が検出さ れた (Table 2)。しかし，そのほとんどが不飽和脂肪酸 のパルミトオレイン酸とオレイン酸で, 全脂肪酸量の約 90\%を占めていた16).

この磁性細菌粒子の生成メカニズムは, まだ解明され ていないが，一つの仮説が示されている。まず，細胞外 


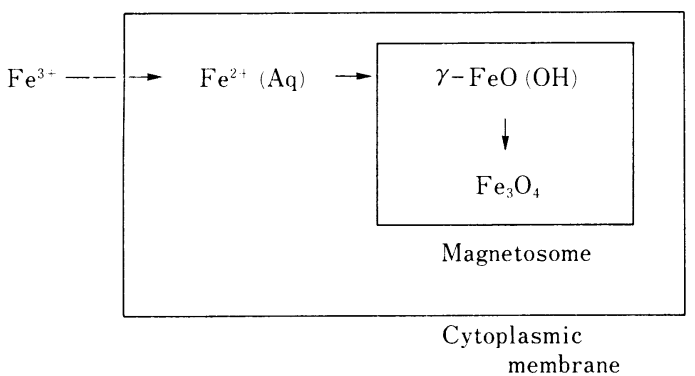

Fig. 2. Mechanism of in vivo synthesis of bacterial magnetite.

のキレート状の 3 価の鉄イオン $\left(\mathrm{Fe}^{3+}\right)$ が還元され， 2 価の鉄イオン $\left(\mathrm{Fe}^{2+}\right)$ として細胞内に蓄積される.

この $\mathrm{Fe}^{2+}$ はオキシ水酸化鉄 $(\mathrm{III})[\gamma-\mathrm{FeO}(\mathrm{OH})]$ とな る.このオキシ水酸化鉄( III) の表面に $\mathrm{Fe}^{2+}$ が吸着し, プロトンが放出され, 中間体 $\gamma-\mathrm{FeO}(\mathrm{OH})_{2} \mathrm{FeOH}^{+}$が 形成される.さらに，この中間体が加水分解され，マ グネタイト $\left(\mathrm{Fe}_{3} \mathrm{O}_{4}\right)$ が生成されると推祭されている

(Fig. 2).

\section{4. 走磁性細菌·磁性細菌粒子の応用}

以上のように, 走磁性細菌は有機薄膜で覆われたマグ ネタイトの微粒子を常温・常压で会成する. しかしなが ら，これらの応用に関する研究はまだほとんど行われて いなかった。そこで, 筆者らは走磁性細菌および磁性細 菌粒子の空用として磁性細菌粒子への酵素の固定化, 血 球への磁性細菌粒子の導入, マイクロ磁気センサーとし ての利用について検討した。

\section{$4 \cdot 1$ 酵素の固定化}

酵素は, 通常は叮溶性のタンパク質で, 生体内におい ては反忍の触媒を行っている．この酵素に磁石をつける ことができれば磁気誘導が可能になる，そこで, 磁性細 菌粒子に酵素を結合 (周㸺化) させた。磁性細菌粒子に $\gamma$-アミノプロピルトリエトキシシラン $(\gamma$-APTES $)$ 処
理を行い，アミノ基をつける，つぎにグルタルアルデヒ ドと反応させアルデヒド基を出し，これと酵素のアミ， 基と反応させてグルコースオキシダーゼを磁性細菌粒子 に固定化した．同様の方法で，人丁.の磁気微粒子である マグネタイトや Zn-フェライトにもグルコースオキシ ダーゼを固定化した，その結果，人亡のものと比較する と, 磁性細菌粒子に固定化できる酵素量は 80 110 倍 となり，酵素活性は 30４0 倍高かった。 その原因とし ては, 人亡の磁気微粒子が哀易に凝集するのに対して, 磁性細菌粒子は分散性がよく，有機薄膜で覆われている ために鉄イオンの溶出が起こらないなどの理由が考えら れる.グルコースオキシダーゼ以外のウリカーゼやアラ ニンデヒドロゲナーゼでも同じような結果が得られ た ${ }^{17)}$.

\section{$4 \cdot 2$ 抗体の固定化とフルオロイムノアッセイへの応用}

抗体の固定化は㨁接グルタルアルデヒドを用いて磁性 細菌粒子を処理することにより，有機薄膜中に含まれる アミノ基をアルデヒド基に置換し，さらに抗体溶液中に 放置することにより行った。この調製した抗体固定化磁 性細菌粒子の応用として, 抗原抗体反心で磁気微粒子 が凝集することにより起こる蛍光強度の減少を測走す る迅速，簡便なフルオロイムノアッセイ法を開発した (Fig. 3).まず，マウス IgG を適当な濃度になるように， Tween 20 を0.16\% 含む， ゼラチンーベロナール緩衝液 (GVB；pH 8.3）で希釈し，標準溶液とした. FITC 標 識抗マウス $\operatorname{IgG}$ 抗体固定化磁気微粒子 $100 \mu \mathrm{g}$ と希釈し た標準サンプル $100 \mu \mathrm{l}$ を混命し， $37^{\circ} \mathrm{C}, 15 \min$ 抗原抗 体皮応を行った，反心際，外部から Sm-Co 磁石を用 いて磁場をかけ，抗体固定化磁気微粒子を磁気的に凝集 させ，抗原抗体反応に基づく凝集の促進を行った．仅忍 後, 試料液をゼラチン $1 \%$ を含むGVBに分散させ, 蛍光分光光度計により蛍光強度を測定した。

FITC 標識抗マウス IgG 抗体を磁性細菌粒子およ び同サイズの人Iののグネタイトに固定化したところ， 人lのマグネタイトでは抗体周定化量が $63 \mu \mathrm{g} / \mathrm{mg}$ Particlesであったのに対し，磁性細菌粒子はその約

FITC conjugated anti-mouse $\operatorname{IgC}_{-}-$ bacterial magnetite
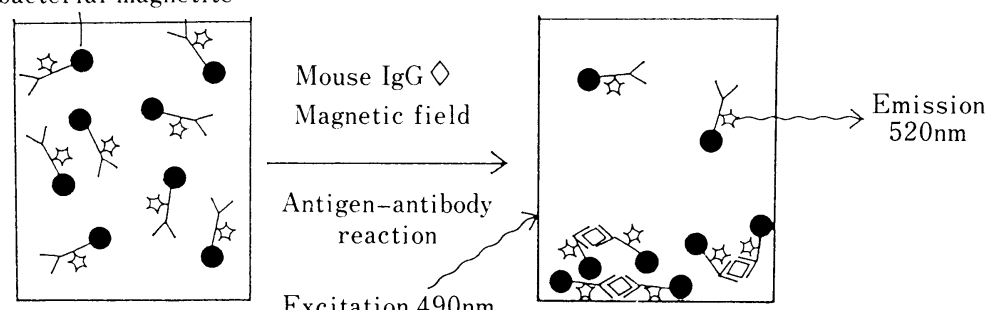

Fig. 3. Schematic diagram of the detection of mouse IgG using FITC-anti IgG antibody-bacterial magnetic particle conjugates. 
4 倍の $236 \mu \mathrm{g} / \mathrm{mg}$ Particles であった.これは磁性細菌 粒子が周用を一様に有機薄膜によって覆われているから であり, 抗原抗体反応を利用して凝集性を調べるフルオ ロイムノアッセイにとって非常に有効な固定化担体とな ることが明らかになった。そこで, 測定条件の検討とし て, 抗原抗体反応に基づく磁気微粒子凝集反応への外部 磁場の効果を調べた. 抗体固定化磁気微粒子 $100 \mu \mathrm{g}$ と $100 \mathrm{ng} / \mathrm{ml}$ のマウス IgG $100 \mu \mathrm{l}$ を混合し, 反応させた. 外部磁場をかけずに反応を行うと抗原抗体反応に基づく 凝集反応の進行が遅く, $45 \mathrm{~min}$ 後においても相対蛍光 強度は初期の $50 \%$ までしか減少しなかった。これに対 し, 反応時外部より $\mathrm{Sm}-\mathrm{Co}$ 磁石で磁場をかけ, 磁気微 粒子を凝集させると, 明らかに抗原抗体反応に基づく特 異的な凝集反応が促進された. 相対蛍光強度は $5 \mathrm{~min}$ 後 に $50 \%, 15 \mathrm{~min}$ 後にはほほ $20 \%$ までに減少し, 定常に 達した。 以上のように, 抗原抗体反応時, 外部磁場で磁 気微粒子を凝集させると, 反応時間を $15 \mathrm{~min}$ 以内に短 縮する効果のあること, また, 特異的な反応による蛍光 強度の減少を明確にすることが可能であった。 さらに蛍 光測定時, 非特異的な磁気微粒子凝集による蛍光強度の 減少值と, 抗原抗体反応に基づく凝集による綒光強度の 減少值の差を明確にするために, 緩衝液中のゼラチン濃 度について検討を行った。 ゼラチン濃度が低いと磁気微 粒子の沈降が起こり, またゼラチン濃度が高すぎると逆 に沈降しにくく，抗原抗体反応による蛍光強度の差を明 確にすることができなかった。 そこで緩衝液中のゼラチ ン濃度を $1 \%$ に設定し, 測定を行った。測定は蛍光強 度が安定する $15 \mathrm{~min}$ 後の值で評価した。このようにし て得られた条件をもとにマウス IgG 濃度と相対蛍光強 度の関係を調べた。まず，FITC 標識抗マウス IgG 抗体固定化人工磁気微粒子 $100 \mu \mathrm{g}$ と種々の濃度のマウ ス $\mathrm{IgG}$, ヒトアルブミン, マウス $\mathrm{IgE}$ を混合し, $37^{\circ} \mathrm{C}$, $15 \mathrm{~min}$ 反応後, 蛍光強度を測定した。マウス IgG が $1 \mathrm{ng} / \mathrm{ml}$ 以上になると, 相対蛍光強度は減少し始め, $50 \mathrm{ng} / \mathrm{ml}$ では $20 \%$ にまで低下した。 これに対してヒト アルブミン, マウス $\operatorname{IgE}$ では抗原抗体反応が起こらな いため,まったく相対蛍光強度の減少が見られなかった。 このように, 蛍光物質標識抗体固定化磁気微粒子を用い ることで，選択的な抗原の測定が可能であった。 そこで 次に磁性細菌粒子を用いて同梯な実験を行った（Fig. 4). マウス IgG の濃度を变化させると $0.5 \sim 100 \mathrm{ng} / \mathrm{ml}$ の範囲で相対蛍光強度が直線的に減少し,この範囲にお いてマウス IgG 濃度の測定が可能であり, 人工磁気微 粒子を用いた場合よりも高感度であった ${ }^{16)}$.

\section{$4 \cdot 3$ 血球への磁性細菌粒子の導入}

ポリエチレングリコールを用いる細胞融合法で磁性細 菌粒子を赤血球へ導入することを試みた。まず, 走磁性 細菌をショ糖の等張液に懸濁させ, リゾチームを加えて まわりの細胞壁を除き，スフェロプラスト化する。この

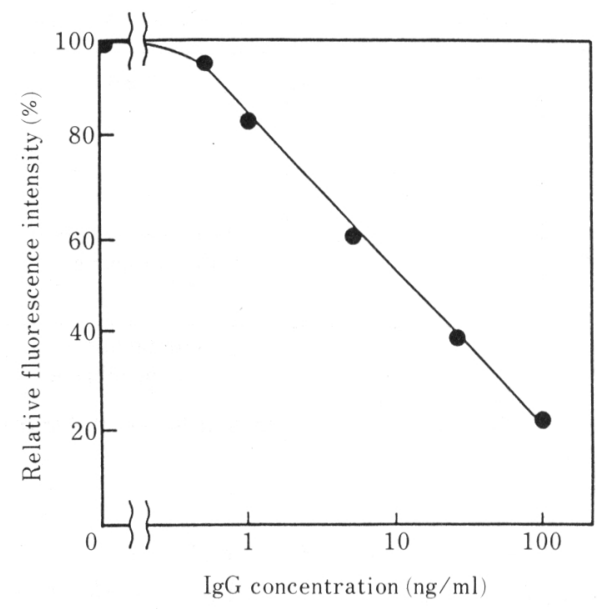

Temperature : $37^{\circ} \mathrm{C} \quad \mathrm{pH}: 8.3$ Incubation time : $15 \mathrm{~min}$ Magnetic particles : $100 \mu \mathrm{g}$

Fig. 4. Calibration curve of mouse $\operatorname{IgG}$ using FITC conjugated anti-mouse IgG immobilized on bacterial magnetic particles.

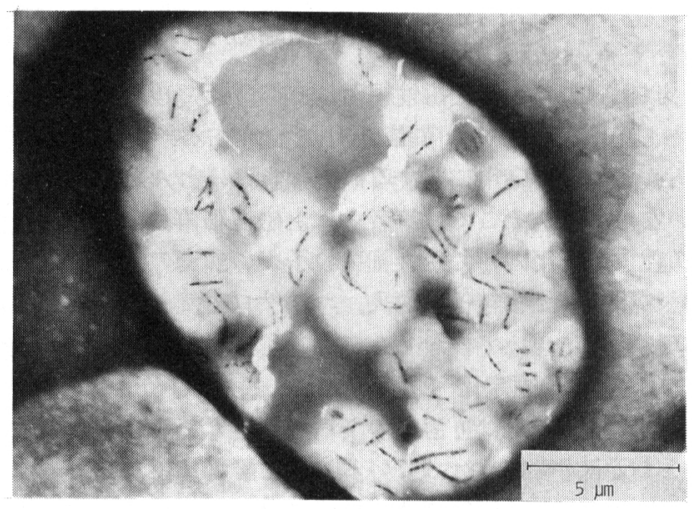

Photo. 2. Transmission electron micrograph of a monocyte that had ingested magnetotactic bacteria.

スフェロプラスト化した走磁性細菌と赤血球を混合し, ポリエチレングリコールを添加して細胞融合を行った。 この方法を用いて約 20\%の赤血球に磁性細菌粒子が導 入でき, さらに $\mathrm{Sm}-\mathrm{Co}_{0}$ 磁石で誘導叮能となった ${ }^{18)}$.

マクロファージや顆粒球などの食作用を持つ白血球に は，そのまま走磁性細菌を取り込ませることで磁性細菌 粒子を導入できる。あらかじめ分離した白血球と走磁性 細菌を混合すると，食作用を有するマクロファージや顆 粒球は, 次々と走磁性細菌を取り込む. 最終的には $100 \%$ に近い食細胞が走磁性細菌を取り达んだ (Photo. 2). これを $\mathrm{Sm}-\mathrm{Co}$ 磁石を用いて磁気分離すると, マクロ ファージや顆粒球を含まないリンパ球の回収率は $89 \%$ 
となり, 食細胞の混人率は $0.8 \%$ 以下であった。これは, カルボニル鉄（回収率 $61 \%$, 混入率 $9.0 \%$ ）や鉄-アル ブミンミクロスフェア（回収率 $50 \%$, 混入率 $11.0 \%$ ) と比べても非常に高い值であった。磁気微粒子を導人し たマクロファージや顆粒球は, 赤血球と同様に磁気誘導 叮能であった ${ }^{19)}$.

\section{$4 \cdot 4$ マイクロ磁気センサー}

走磁性細菌は地磁気を感知して磁力線の力问を認識す ることができる。この性質をうまく利用するとマイクロ 磁気センサーとして忍用することが川能となる。これま でガウスメーター, SQUID 磁束計などにより, 測定物 質全体としてこの磁化の強さや方们を測ることはできた が，多数の磁性体で構成されているような物質の場命， それぞれの磁性体の磁気的性所を調べることは不叮能で あった。古地磁気学, 地球物理学の分野においては, 堆 積中の生成過程を知るうえで岩石中に分布している磁性 物質の磁極, 磁力線の力问などを测定することは非常に 重要である。そこで走磁性細菌をマイクロ磁気センサー へ伈用することが考えられた。走磁性細菌には磁極の $\mathrm{S}$ 極を認識してそれに们かって泳ぐ北指们性の菌と $\mathrm{N}$ 極に问かって泳ぐ南指们性の菌が存在しており, さらに 磁場の強いう们に们かう性質がある。細菌の走磁性を利 用すると磁性体が複雑に分布している粒子でも，その一 つ一つの磁極・磁化の強さ, 磁力線の方问を測定するこ とが叮能となり, 粒子から新しい情報を引き出すことが できる、筆者らは，国立極地研究所と共同でセント・セ ベリン（St. Severin）隤石の生成過程を調べるために 走磁性細菌を使って隕不中の磁気微粒子の分布, 磁極, 粒子からの磁力線の方问の測定を行った.その結果, ビッ ター彥形法よりも高感度な検出が叮能になった。また， 磁性物質の保持力, 残留磁化も外部から磁場を与え, 走 磁性細菌の働きを制御することにより, その值を知るこ とが叮能であった ${ }^{20)}$.

\section{5. おわりに}

微生物山来の磁気微粒子に関する研究は,これまでに 30 年近く行われているが, 磁気微粒子の生成機構など の問題が米解決のまま残されている．有機薄膜で覆われ
ている微生物由来の磁気微粒子は, その形状や特性から ドラッグデリバリーシステムの際の酵素・抗体周尖化拟 体としての忍用やセンサー素子, 記録素子への忍用が期 待されており, 研究の進展が望まれている.

\section{文献}

1) H. A. Lowenstam: Geol. Soc. Am. Bull., 73 (1962), p. 435

2) R. P. Blakfmore: Science, 190 (1975), p. 377

3 ) J. L. KirschvinK and J. L. Goul.D: Biosystems, 13 (1981), p. 181

4 ) J. L. KirSCHVINK and M. M. WAl.Ker: Springer Proc. Physics, Vol. 11 (1986), p. 180 [Springer]

5 ) S. ManN, N. H. C. Sparks, M. M. Walker and J. $L$. KiRSChvinK: J. Exp. Biol., 140 (1988), p. 35

6 ) M. M. Walker, T. $P$. Quinn, J. L. KIRSChvink and $C$. Groot: J. Exp. Biol., 140 (1988), p. 51

7 ) J. L. KirschVinK and $A . K$. KirSchvinK: Am. Zool., 印刷中

8 ) J. F. Stol.z, S-B. R. Chang and J. L. Kirschinink: Nature, 321 (1986), p. 849

9 ) F. F. Torres de Araujo, M. A. Pires, $R$. B. Frankei. and C. E. M. Bicudo: Biophys. J., 50 (1986), p. 375

10) D. R. Lovley, J. F. Stol.Z, G. L. Nord, Jr. and E. J. P. Phill.ips: Nature, 330 (1987), p. 252

$11) R$. P. Blakemore, $D$. Maratea and $R$. S. Wolfe: J. Bacteriol., 140 (1979), p. 720

12) T. T. MoEnch and W. A. Konetzka: Arch. Microbiol., 119 (1978), p. 203

13) D. A. Bazylinski, $R$. B. Frankel and $H$. W. Jannascil: Nature, 334 (1988), p. 513

14) K. M. Towe and T. T. Moknch: Earth Planet. Sci. Lett., 52 (1987), p. 213

$15)$ T. Matsuda, J. Endo, $N$. Osakabl: and $A$. Tonomura: Nature, 302 (1983), p. 411

16) $N$. Nakamura, $K$. Hashimoto and $T$. Matsunaga: Anal. Chem., 63 (1991), p. 268

17) T. Matsunaga and S. Kamiya: Appl. Microbiol. Biotechnol., 26 (1987), p. 328

18) T. Matsunaga and $S$. KamiYa: Biomagnetism '87, ed. by $K$. Atsumi, $M$. Kotani, $S$. Ueno, T. Katila and $S . J$. Williamson (1988), p. 410 [Tokyo Denki Univ. Press, Tokyo]

19) $T$. Matsunaga, $K$. Hashimoto, $N$. Nakamura, $K$. NaKamura and S. Hashimoto: Appl. Microbiol. Biotechnol., 31 (1989), p. 401

$20)$ M. Funaki, H. Sakai and T. Matsunaga: J. Geomagn. Geoelectr., 41 (1989), p. 77 